\title{
Design and Simulation of Boost Converter Using P \& O Technique for PV System
}

\author{
Patel Mamta Z. ${ }^{1}$, T. B. Maniar ${ }^{2}$ \\ ${ }^{1}$ PG student, Department of Electrical engineering, Shantilal Shah Engineering College, Bhavnagar \\ ${ }^{2}$ Assistant Professor, Department of Electrical Engineering, Shantilal Shah Engineering College, Bhavnagar
}

\begin{abstract}
This paper represents to provide modeling of PV cell. The voltage available at PV Panel terminals. It is continuously changing and it needs to be processed by electronic converters for constant voltage output. A DC-DC converter topology of the converter is selected to step up or step down the input voltage. This is kept output voltage constant. MPPT techniques are used to obtain maximum power which is get by the PV panel. The function of MPPT to operate the PV array. Now days, many algorithms for MPPT. But P and O method is very simple between them.
\end{abstract}

Keywords: PV arrays, MPPT, P and O method, DC-DC converter

\section{Introduction}

The necessary of energy for many applications likes transportation application, household requirement, office requirement and industrial application. Since the use of energy become integral part of our life. There are much renewable or non-renewable energy. The current trends in energy consumption are neither secure nor sustainable. The increasing consumption of fossil fuels together with rising greenhouse gas emission.

There are renewable energy sources such as biomass, wind, solar, mini-hydro etc. To use of advanced power electronic technologies, the solar and wind energy sources are mostly used.

\section{Photovoltaic Cell}

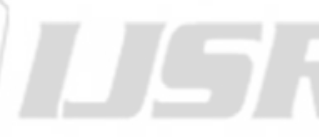

When the sunlight exposed, solar cell produced DC voltage. Generated DC voltage varies with light irradiance. Solar cell is a non-linear current source. The current which is produced by solar cell is depends on the irradiation, cell temperature, characteristic of material and age of cell.

\subsection{Photovoltaic power system}

The irradiance energy convert into electric energy without using mechanical mechanism is called photovoltaic phenomenon. This phenomenon has been based on the practical theory of irradiated energy. The system which is used this irradiated system is called photovoltaic system. System consists three part one of is solar module second one is interface part and last third one is electric load. The second part can manage and induced energy. This energy obtain form PV system.

\subsection{PV Module}

The power produced by only one PV is not enough for general use. So many PV cells are connecting in series or parallel to get desired power. Mostly the series connection is known as a module. One module consist approximately 36 or 72 cells. And also consists back-side, front side. The front side made up by low iron and tempered glass. The efficiency of PV cell is greater than the PV module. Block diagram of $\mathrm{PV}$ cell is shown in figure-1.

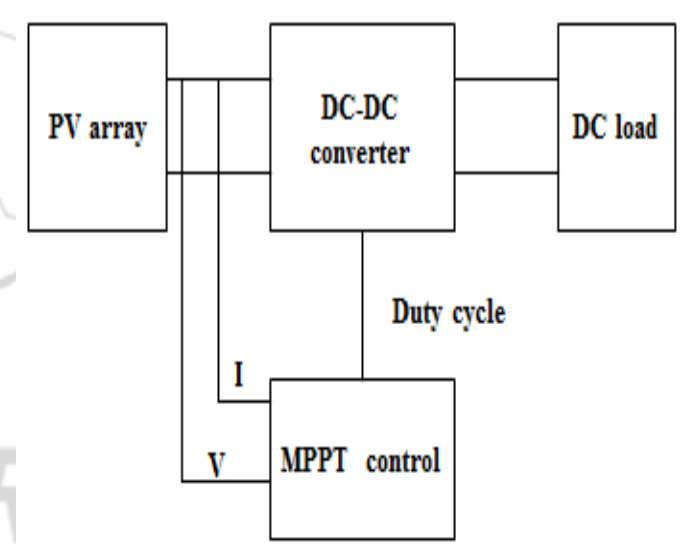

Figure-1: Block diagram of PV cell

At the terminals of the photovoltaic, the electricity available, which cannot be fed to the grid connected load due to the fluctuation of the sunlight. So, the electronic converter used for constant supply from the PV panle. These DC-DC converters regulate voltage and current fed to the load. A DCDC converters can be a step up or step down. A Boost converter is selected to step up voltage. These voltage available at the PV cell. By controlling the duty cycle to keep the solar panle operating at its maximum power point. The MPPT algorithm use to calculate the absolute power. It takes the voltage at the maximum power point and converts into the voltage maximum power point.

Basically a solar panel cell is a $\mathrm{p}-\mathrm{n}$ junction. When sunlight exposed, a DC current is generated. This equivalent circuit is act as a current source with diode. The equivalent circuit of solar panel is shown in figure-2. 


\section{International Journal of Science and Research (IJSR)}

ISSN (Online): 2319-7064

Index Copernicus Value (2013): 6.14 $\mid$ Impact Factor (2015): 6.391

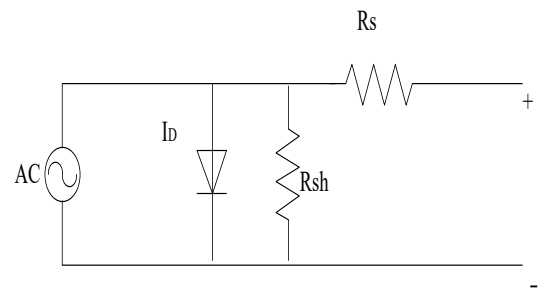

Figure 2: Equivalent circuit of solar panel

The basic mathematical equation of $\mathrm{I}-\mathrm{V}$ characteristics of ideal PV cell is given below,

$$
\mathrm{I}=\mathrm{Ipv}-\mathrm{I}_{0}[\exp (\mathrm{qV} / \mathrm{akT})-1]
$$

The diode current:

$$
\mathrm{Id}=\mathrm{I} 0[\exp (\mathrm{q}(\mathrm{V}+\mathrm{IRs}) / \mathrm{KT}))-1]
$$

Solar output current:

$$
\begin{gathered}
\mathrm{I}=\mathrm{IL}-\mathrm{Id}-\mathrm{Ish} \\
\left.\mathrm{I}=\mathrm{IL}-\mathrm{I}_{0}[\exp (\mathrm{q}(\mathrm{V}+\mathrm{IRs}) / \mathrm{KT}))-1\right]-(\mathrm{V}+\mathrm{IRs}) / \mathrm{Rsh}
\end{gathered}
$$

Ipv $=$ current generated by the incident light

Id = Diode current (A)

$\mathrm{I}_{0}=$ Reverse saturation current of the diode $(\mathrm{A})$

$\mathrm{q}=$ electric charge $[1.60 \mathrm{e}-19 \mathrm{C}]$

$\mathrm{k}=$ Boltzmann constant $[1.85 \mathrm{e}-23 \mathrm{~J} / \mathrm{K}]$

$\mathrm{T}=$ Temperature of $\mathrm{p}-\mathrm{n}$ junction $(\mathrm{K})$

\section{DC-DC Boost Converter}

In a boost converter the output voltage is greater than the input voltage. A boost converter using a power MOSFET shown in figure-3.

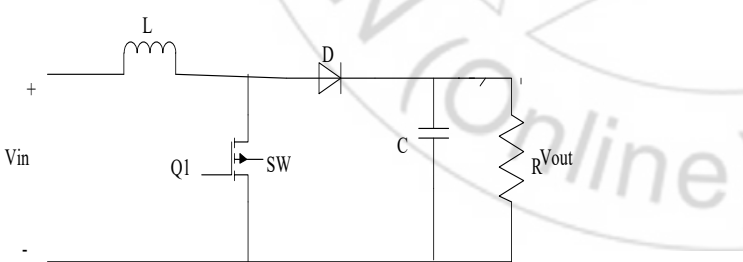

Figure 3: Circuit diagram of boost converter

The circuit operation has two modes. In mode 1 , power MOSFET switched on at $\mathrm{t}=0$. Input current rises and flow through inductor and switched Q1. Whereas in mode 2 the switched off at $\mathrm{t}=\mathrm{t} 1$. So, the current flow through inductor, capacitor and diode. The energy stored in the inductor will be transferred to the load.

\subsection{Boost Converter and Power Design}

Table 1: Specification of Boost Converter

\begin{tabular}{|c|c|}
\hline Input voltage (Vs) & $12 \mathrm{~V}$ \\
\hline Output voltage (V0) & $48 \mathrm{~V}$ \\
\hline Output power (P0) & $120 \mathrm{~W}$ \\
\hline Duty cycle (D) & $0.25-0.75$ \\
\hline Output current (I0) & $2.5 \mathrm{~A}$ \\
\hline Input current (Is) & $10 \mathrm{~A}$ \\
\hline Output resistance (R) & $19.2 \Omega$ \\
\hline Switching frequency (f) & $50 \mathrm{kHz}$ \\
\hline Inductor value (L) & $0.052 \mathrm{mH}$ \\
\hline Stored energy in inductor (E) & $0.00036 \mathrm{~J}$ \\
\hline
\end{tabular}

\section{MPPT Technique}

What is MPPT? MPPT means maximum power point tracking. To reduce the solar cost by decreasing the number of solar panels, MPPT is important in solar system. A MPPT is used for extracting from the solar panel and transferring that power from PV module to the load. The DC-DC boost converter interface between the load and the PV module. The load impedance is varied by changing the duty cycle. This varied impedance matched at the peak power. Maximum power point varies and depends on the temperature of cell or also depends on the preset insolation level. MPPT done for maximum power output.

There are three method of MPPT

- Perturb and observe method

- Incremental conduction method

- Constant voltage method

\subsection{Perturb and observe method}

To modifying the operating voltage or current of the photovoltaic panel until you obtain maximum power from it. It is the main concept of perturb and observe method. This method have only one voltage sensor. This method also known as 'hill climbing' method. This is due to the fact that on the left side of the MPP the curve rises $(\mathrm{dP} / \mathrm{dV}>0)$ whereas on the right side the curve is falling $(\mathrm{dP} / \mathrm{dV}<0)$. This process depend on the increasing or decreasing the duty cycle.

The major drawback of this method is that under steady state condition, the output power oscillates the maximum power point.

Firstly, in this method the PV voltage and current are measured and then calculate the corresponding power. When the power change is less than or equal to the preset value, assume that the system enters in the steady state. After then the perturbance becomes small. The $\mathrm{P}$ and $\mathrm{O}$ algorithm shown in figure-4. 


\section{International Journal of Science and Research (IJSR)}

ISSN (Online): 2319-7064

Index Copernicus Value (2013): 6.14 | Impact Factor (2015): 6.391

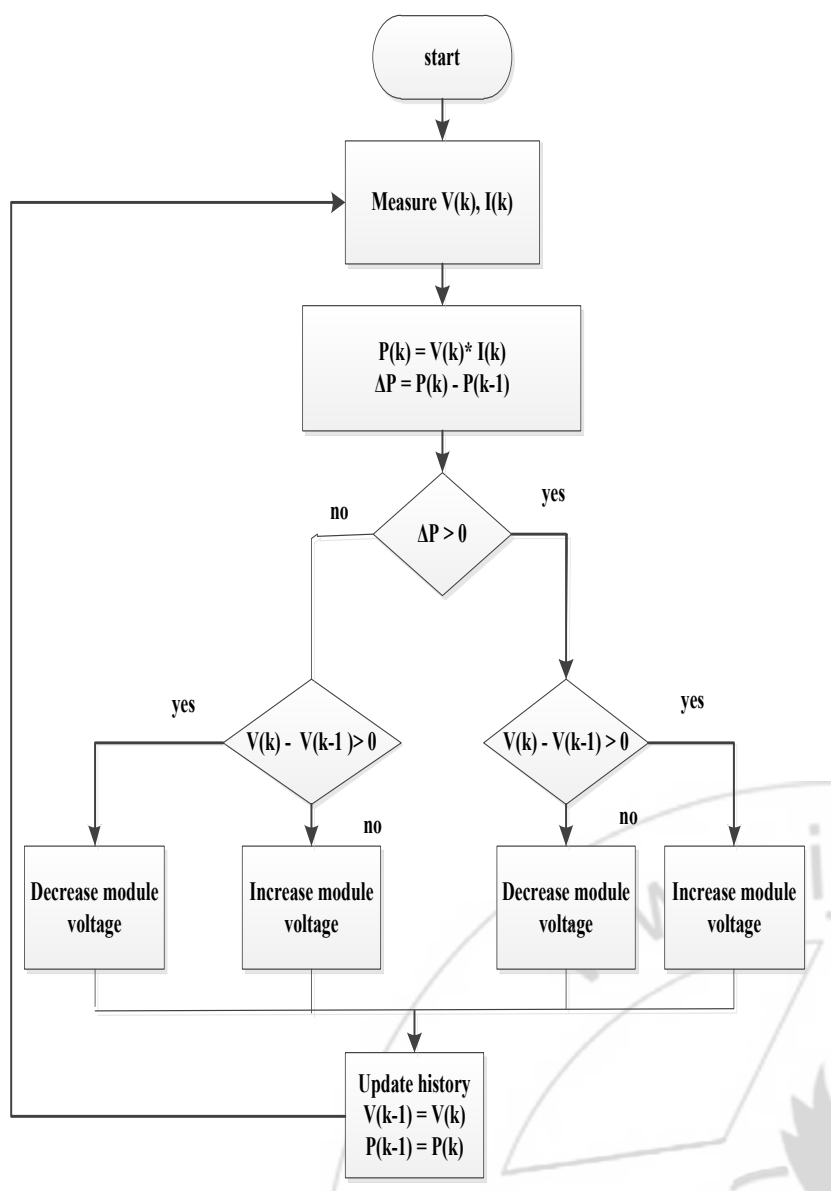

Figure 4: Purturb and observe algorithm

\subsection{Incremental Conduction method}

The disadvantage of perturb and observe method id overcome by the incremental conduction method. This method based on the slop of the power curve of the panel. At the MPP it is zero. Positive to the left and negative to right. This method has two sensors such as voltage and current sensor.

$\frac{d P}{d V}=\frac{d(I V)}{d V}=\mathrm{I}+\mathrm{V} \frac{d I}{d V}(5)$

By rearranging equation (5)

$\frac{\mathrm{dI}}{\mathrm{dV}}=-\frac{I}{V}$ at MPPT $(6)$

$\frac{\Delta I}{\Delta V}>-\frac{I}{V}$ left of the MPP (7)

$\frac{\Delta I}{\Delta V}<-\frac{I}{V}$ right of the MPP (8)

At the MPP Vref $=$ VMPP

The MPP can tracked by comparing the instantaneous conduction to the incremental conduction. Voltage at MPP varied in atmospheric conditions. The algorithm shown in figure-5.

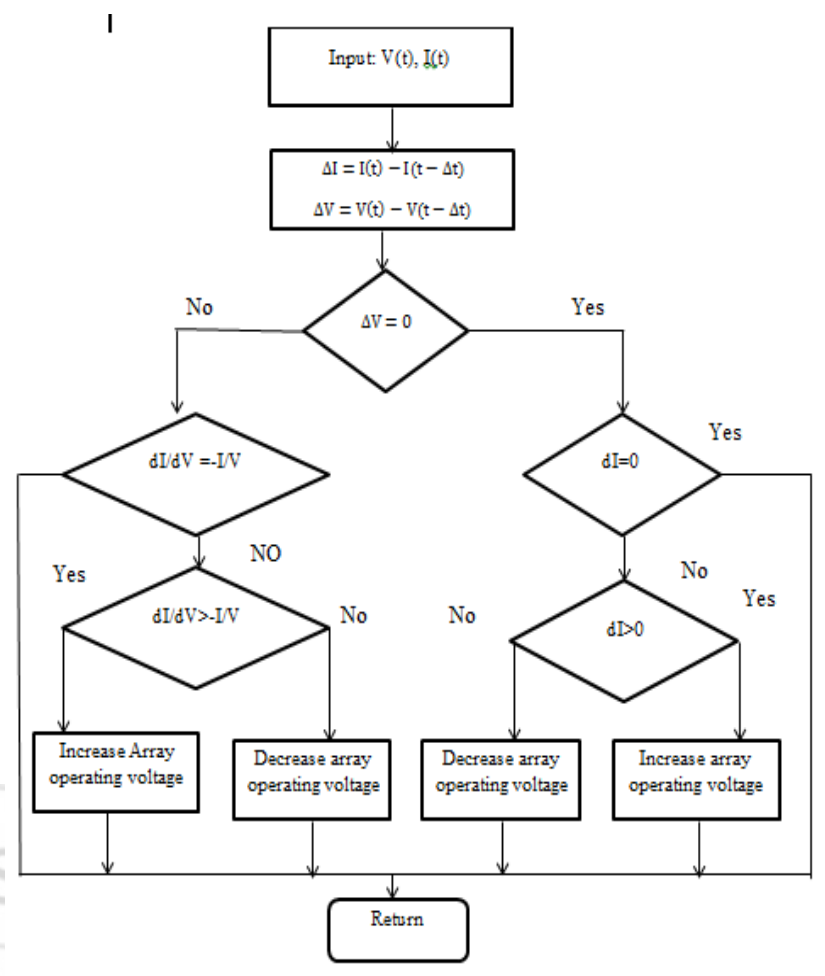

Figure 5: Incremental conduction algorithm

\subsection{Constant Voltage method}

The constant voltage algorithm is that the ratio of the arrays maximum power voltage at MPP. In open circuit the voltage is approximately.

$\mathrm{Vmpp} / \mathrm{Vc}$ is approximately $\mathrm{K}>1$.

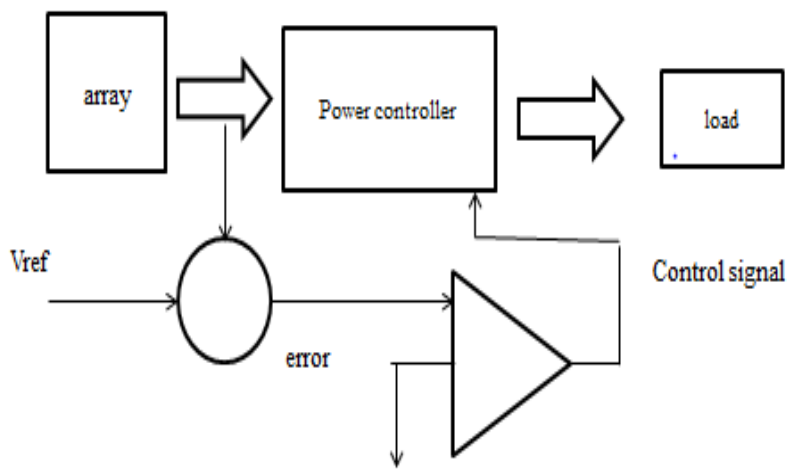

Figure 6: MPPT circuit of IncCond method

Algorithm of constant voltage method can be implemented by above figure. To measure Voc, the solar array can be isolated temporarily. Than the MPPT calculates the correct operating point by using equation (9). This method is extremely simple but difficulty is that to choosing constant $\mathrm{K}$. 


\section{MATLAB Simulation}

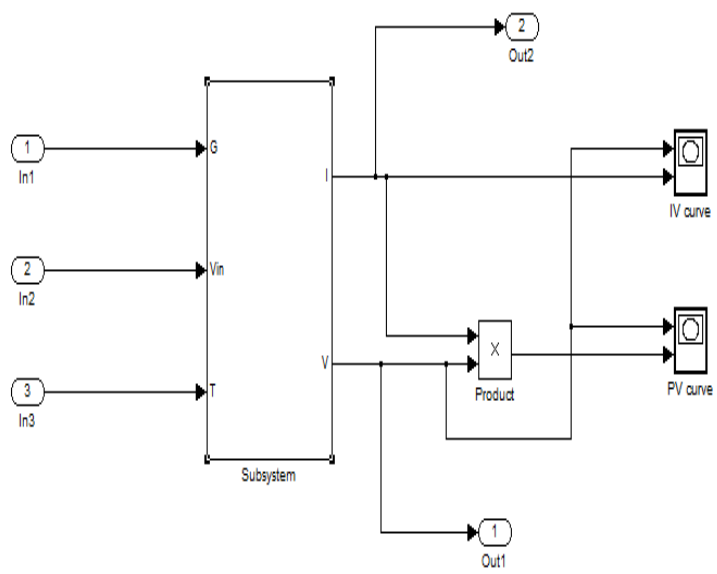

Figure-7: PV Array

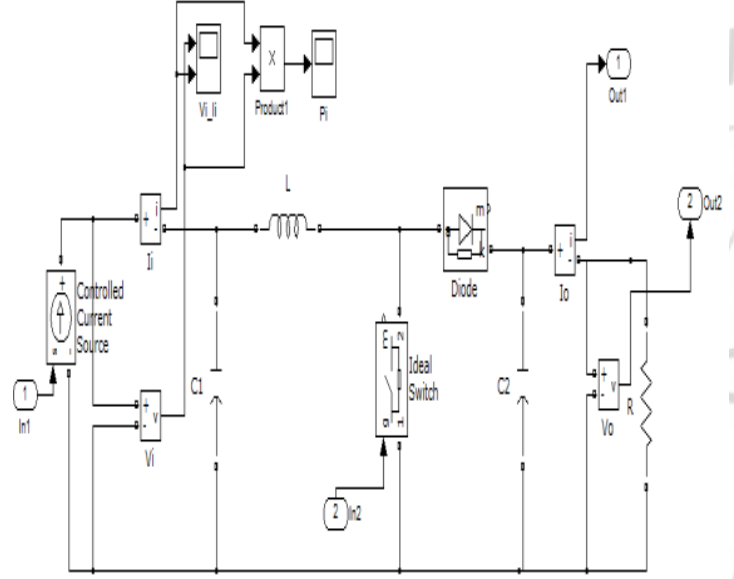

Figure-8: Boost Converter

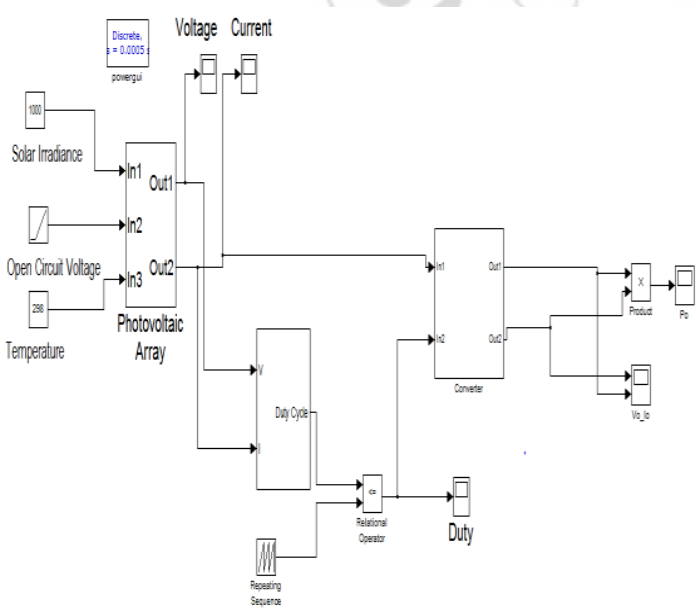

Figure-9: Combined circuit of $\mathrm{P}$ and $\mathrm{O}$ Technique

\section{Simulink Results}

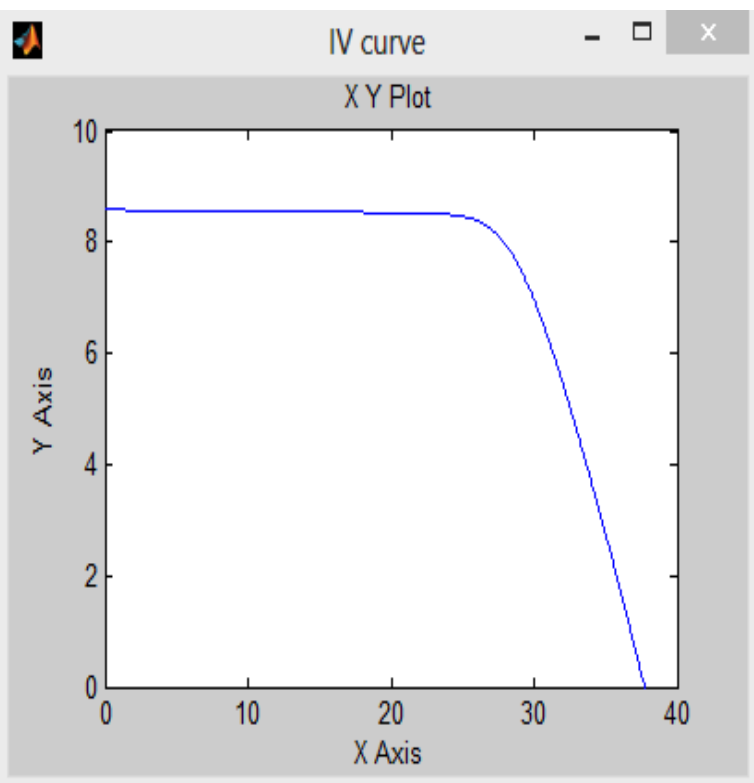

Figure-10: IV Curve

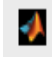

PV curve

- $\square x$

$\lambda$ XY Plot

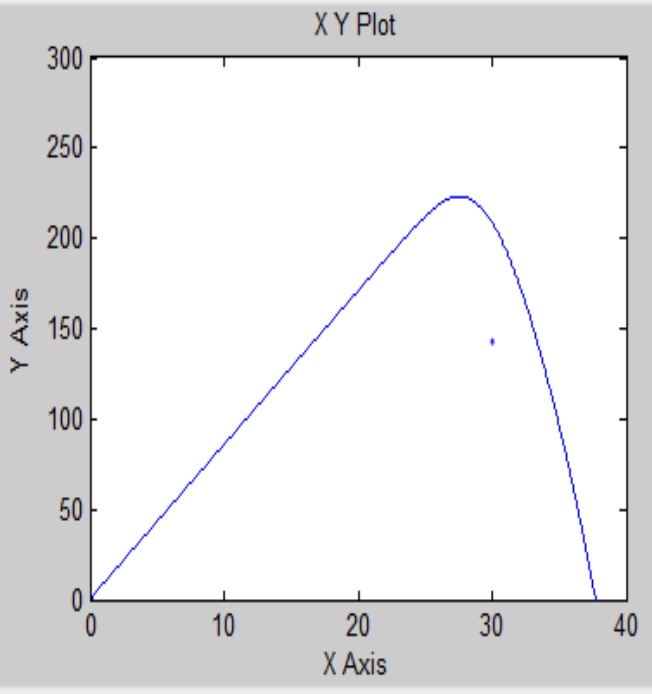

Figure-11: PV Curve

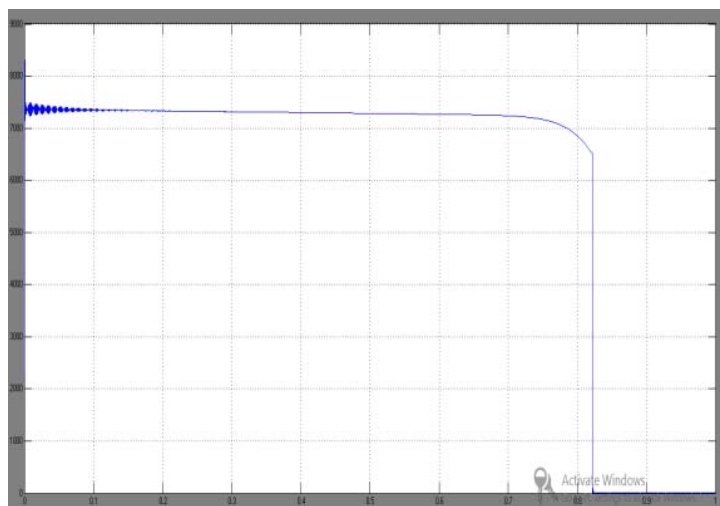

Figure 11: MPPT power 


\section{International Journal of Science and Research (IJSR) \\ ISSN (Online): 2319-7064}

Index Copernicus Value (2013): 6.14 | Impact Factor (2015): 6.391

\section{Parameters of Model}

\begin{tabular}{|c|c|}
\hline Parameters & Parameters Values \\
\hline Irradiance & $1000 \mathrm{~W} / \mathrm{m}^{2}$ \\
\hline Pulse Generator Parameters: & \\
\hline Pulse Amplitude & 1 \\
\hline Period & 0.005 \\
\hline Pulse Width & 35 \\
\hline Phase Delay & 0 \\
\hline Pulse Type & Time Based \\
\hline Maximum power (Pmax) & $7100 \mathrm{~W}$ \\
\hline Current at Pmax (Imp) & $8.99 \mathrm{~A}$ \\
\hline Voltage at Pmax (Vmp) & $37.8 \mathrm{~V}$ \\
\hline Temperature Coefficient (K) & $0.00060 \mathrm{~K}$ \\
\hline Electron charge $(\mathrm{q})$ & $1.6^{*} 10^{-3} \mathrm{C}$ \\
\hline Boltzman Constant $(\mathrm{K})$ & $1.38 * 10^{-23} \mathrm{~J} / \mathrm{K}$ \\
\hline $\begin{array}{c}\text { Solar Cell Series Resistance } \\
\text { (Rs) }\end{array}$ & $0.42 \Omega$ \\
\hline $\begin{array}{l}\text { Solar Cell Parallel Resistance } \\
(\mathrm{Rp})\end{array}$ & $400 \Omega$ \\
\hline Ns & 36 \\
\hline Irradiance & $298 \mathrm{~K}$ \\
\hline $\mathrm{N}$ & 1.2 \\
\hline Inductance $(\mathrm{L})$ & $1 \mathrm{e}-3 \mathrm{Mh}$ \\
\hline Capacitance $(\mathrm{C})$ & $1 \mathrm{e}-6 \mu_{\mathrm{H}}$ \\
\hline Resistance (R) & $100 \Omega$ \\
\hline
\end{tabular}

\section{Conclusion}

Analysis of PV array is done by mathematical analysis. The method obtains the parameters of the I-V equation by using the following nominal information from the array datasheet: open-circuit voltage, short-circuit current, maximum out- put power, voltage and current at the maximum power point, current/temperature and voltage/temperature coefficients. I-V curve and P-V curve of the PV array are obtained. MATLAB models for open loop controlled boost converter system for photovoltaic installation are developed using the blocks of Simulink and the same are used for simulation studies

\section{References}

[1] Chetan Singh Solanki, "Solar Photovoltaics Fundamentals Technologies and applications", IEEE press.

[2] Azad Safari, Sadd Mekhiled, "Simulation and Hardware Implementations of Incremental Conduction MPPT with Direct Control Method using cuk converter". IEEE Transaction on electronics, March 2011.

[3] D.P.Hohm, M.E.Roop, "Comparative study of Maximum PJay Patel, Vishal Sheth, Gaurang Sharma, "Design \& Simulation of Photovoltaic System using Increment MPPT Algorithm”. IJAREEIE, Vol.2, Issue 5, May2013

[4] Johan H.R.Enslin, M.S. Wolf "Integrated Photovoltaic Maximum Power Point Tracking Converter". IEEE Transactions on industrial electronics. Vol.44

[5] Sanjeev Sharma and Sonia, "Simulation Model of boost converter used in Photovoltaic System". International Journal.

[6] Marcelo Gradella Villava, Jonas Rafael Gazoli and Ernesto Ruppert Filho, "Comprehensive Approach to Modeling and Simulation of Photovoltaic Arrays". IEEE Transaction on Power Electronics, vol. 24,no.5, May 2009
[7] Bidyadhar Subhudhi and Raseswari Pradhan, "A Comparative Study on Maximum Power Point Tracking Techniques for Photovoltaic Power Systems", IEEE transactions, January 2013.

[8] Hairul Nissah Zainudin, "Comparison Study of Maximum Power Point Tracker Techniques for PV System". Proceeding of the 14th International Middle East Power Systems Conference. December 19-21, 2010.

[9] Savita Nema. R.K. Nema, Gayatri Agnihotri, "Matlab/Simulink based study of Photovoltaic cells/modules/array and their Experimental Verification. IJEE, Vol.1, Issue 3, 2010.

[10] J. P. Benner and L. Kazmerski, Photovoltaics gaining greater visibility, IEESpectr.vol. 29,34-42

[11] Balakrishna S, Thansoe, Nabil A, Rajamohan G, Kenneth A.S., Ling C. J."The Study and Evaluation of Maximum Power Point Tracking Systems", International Conference on Energy and Environment 2006.

[12] Design and Simulation of Boost Converter for Constant Output Voltage Brijesh M. Patel, Minesh k. Joshi and Dhaval N. Tailor

[13] Review Of An Inverter For Grid Connected Photovoltaic (PV) Generation System Prakash Kumar Dewangan, U .T. Nagdeve.

[14] Mr. Shrusti R. chafle, "Converter Design MPPT technique”.

[15] M.H.Rashid, "Power Electronic Devices, circuit and application". 3rd edition.

[16] Mohan, Undeland, Robbins "Power electronics: converters, applications and Design, 3rd edition (WSE series)".

[17] A. Pradip Kumar Yadav, "Comparison of MPPT Algorithms for DC-DC Converters Based PV Systems". IJARE. Vol.1, Issue 1, July 2012.

[18] International Journal of Research in Electrical and Technology, Amarnath Kurella, R Suresh, "Simulation of Incremental Conduction MPPT with direct control method using Cuk Converter".

[19] Journal of Power and Energy Engineering 2014, "Overview of MPPT Control Method for Photovoltaic System".

[20] S. Gomathi. S.S. Saravanan. Dr. S. Thangaval, "Design and Implementation of Maximum Power Point Tracking Algorithm for a Standalone PV system", IJSER, Vol 3, Issue 3, March 2012.

[21] Eftichios Koutroudis, Kotas kalaitzakis and Nicholas C. Voulgaris, "Development of Microcontroller Based, Photovoltaic Maximum Power Point Tracking Control System. IEEE Transaction on Power Electronics, vol 16, No.1, January 2001.

[22] IJESRT journal, Ms. Shrusti R. Chafle, Mrs. Megha A. Gadekar, "Converter using MPPT Technique".

[23] T. Sridhar, Anish Kumar J. "Development of Solar MPPT System using Boost Converter with Microcontroller", vol 1, Issue 4, October 2012.

[24] P. Sathya, Dr. Natarajan, IJET, "Design and Implementation of $12 \mathrm{~V} / 24 \mathrm{~V}$ Closed loop Boost Converter for Solar Power LED Lighting System" 